\title{
Human rights perspective of the older popu- lation in the COVID-19 pandemic in Turkey
}

\author{
Dicle Kaya ${ }^{1}$, Burhanettin Kaya² \\ ${ }^{1}$ Student, Bogazici University, Faculty of Administrative and Economic Sciences, Political Science and International Relations, Istanbul, \\ Turkey \\ ${ }^{2}$ Doç. Dr. Private Office, Şişli, İstanbul, Turkey
}

\section{TO THE EDITOR}

Starting in May 2020, the world got in a serious challenge as COVID-19 swept across the world, forcing states to put aside current affairs and taking immediate measures to contain the outbreak. Such a global alarming epidemic has never been seen before, it may be historically a one of a kind if we consider the ability of the virus to rapidly spreading over large areas. Thus, this period of the outbreak was marked by the extreme measures that were overlapping with the businesses, relationships, educations and most importantly, freedoms and rights of people across the world. The freedom of movement, the right of privacy, right to access to health, freedom of expression and freedom of information are some of the rights and freedoms that were overlapping with the government policies which aim to conserve the public health. Epidemics and disasters are the conditions that justify violations of rights if they are proportionate to the limitations.

In these serious times, the older population experienced worse challenges. Because the older population were declared by medical institutions as fragile human beings and are vulnerable to the virus, the old generation becomes a target for extra protection. Despite the delicacy, countries in the world such as Sweeden and UK were late to act upon protecting the old people. Some scholars evaluate this reluctance of action as a way of putting less worth on the old population referring to their less contribution to the labour force and economic market. When faced with a national alarming pandemic, governments have a tendency to neglect the margins in the society, such as older people and disabled people, and allocate resources against their needs (1).

In addition, developing and underdeveloped countries also struggled to balance the already weaken- ing economy and the allocation of resources for the protection of public health. According to the NGOs providing assistance in lots of countries, elder abuse and neglect intensified with the upcoming pandemic. HelpAge points out that according to the reports, old people face rising physical and psychological abuse, robberies or being left to die in some healthcare facilities (2). Turkey, in this sense, may have adequate government attention towards the older population in the healthcare facilities according to some researches. However, from the perspective of foundations advocating elders rights, the approach towards the elders flourished by the media gained a discriminative sense of protection and the government policies has a downside effect contributing to the marginalisation of the elders. There have been occasional lockdowns, at the weekends, with other limitations encompassing the whole population disregarding race, age and sex. Especially, the people over 65 years old faced more limitations such as lockdowns and restrictions of using public transport. These further arrangements omit the negative influence upon old people; the psychological effects of the social isolations as well as the economic struggles which the employed old population face when they are obliged to stay at home or prohibited from using public transportation. Plus, infected old patients are occasionally pushed behind younger patients in terms of the priorities. In this matter, it can be said that the media-fueled public opinion's distorted views on the older generation as they are "weak" with the parallel practices of the public institutions towards the old people lead them to be deprived of living humanely. In sum, government measures taken for COVID-19 such as lockdowns, self-isolations and hospital restrictions pose a threat of human rights on the matter of proportionality, violate the rights of old people in the aspects of the right to non-discrimination, right to private life and freedom of movement in Turkey. 
While preparing my research, I made use of internet resources, mainly from global news platforms and online published reports of NGOs and CSOs and also existing literature including researches on Turkey and other countries' implications.

Firstly, reviewing the global stance towards the elderly people, Supriya Akerkar draws attention to the human rights violations in COVID-19 targeting older people and people with disabilities. She suggests that the period of COVID-19 reveals the hierarchical social construction of our society, the existing ageism and disablism lead to the practices of stereotyping and discrimination. It is important to see these discriminative actions come from the formerly accepted medical categories of impaired, weak and older bodies against the idea of a 'normal' body. She states that "An analysis of the discourse about COVID-19 and its effects shows that it contributes to the further stereotyping of people with disabilities and older people as less useful and valued, and more as a burden to the society, with an underlying message that it is acceptable for these groups to die." (3). In such a society, Akerkar indicates that appealing to human rights is significant to establish politics that recognize the iterated groups, consults to them about the areas that affect their lives and designs communication systems that make information accessible to them.

The Turkish researches on the condition of older people in Turkey are mainly criticising ageism towards the actions of the younger generation in the social media platforms who put every being on the internet as a tool of humour and entertainment $(4,5)$. There is no significantly mentioned criticism on governments actions, the fault is mostly given to the civilians such as the social media perpetrators and the lynch culture, in other terms, cyberbullying. It can be said that there is a consensus on a revealing of existing ageism structures with the pandemic. Zeynep Altın emphasizes that the role of media and the government's warnings which raise the panic and anxiety centred around the old population, leading elderly people being portrayed as "dangerous" instead of "in need of protection" (6). Her research does not give information about the violations of rights of older people but she argues the risks and challenges older people face from the government policies, for instance, the quarantines causing further social isolation with swift mental desperation of being lonely for a long time. Also, because the measures taken to avoid social isolation are mainly virtual on the internet, these produce inequalities in accessing the service. Together with it, the sphere of social media is dominated by the younger population. Altm points out that the portrayal of the old population as "the other" in the social media deepens the ageist perceptions.

Sevim Atila Demir (7) also emphasizes the strong psychological effects on the elderly people and the raising ageism puts them in danger of being targeted for hate crimes. She asserts that the main reason for these targeted actions is the tendency of perceiving old people as a homogenous whole, or as a bulk of people whose lifestyle and culture is completely different from society. However, the old population in Turkey is the most heterogenic group in society (7). There she examines the social status alterations people face while ageing and puts this process as the root of splitting the age groups in society. As like Altın, Demir doesn't mention the violation of rights, but she suggests that the difficulties experienced in the context of the old population may also be a consequence of rapid growth of the share of the old population in the country, and correspondingly, the lack of service capacity government can give to the upcoming mass.

Similarly, in the press release of the +65 Elderly Rights Foundation, the main argument is that the old population is not a homogenous cluster and it is not equal to be cut off from the societal and economic organizations (8). Every person over 65 doesn't possess the conditions that of an assumed risky unhealthy old person. A great amount of people as a member of +65 has to work for a living and as they age, their earnings decrease because their share in the market diminishes. In addition, lots of old person needs physical activity throughout the day, walking in fresh air necessary for their health improvement. The older people who live alone also need their basic needs to be met but the services local administrations provide are falling short. Restrictions without making certain social arrangements or policies create discrimination against the elderly. 
If we look at the executions in legal terms, there are substantial instances that cause controversy on the necessity and proportionality of these executions. In the Turkish constitution, it is particularly indicated in Article 13 that the foundational rights and freedoms cannot be violated unless there occurs a state of emergency which clearly pose a threat to public health. If there is a state of emergency, the limitations or suspensions of rights should be justifiable, necessary and proportionate (9). The order of lockdowns should get through the legislative branch and the time span should be informed in the memorandum. On the other hand, when we look at the lockdown order involving the old people above 65 , it does not have an estimated time span. Thus the indefinite time period announcements gives the feeling of arbitrariness. Also, when the restrictions were gradually removed in the 'normalization' period starting with June, the restrictions on old people were not removed. Yet, if the government aims to violate the basic rights of the people, its implementation is required to be certain and clear. We see no such clarification about the future of lockdown when it comes to the older people.

European Convention of Human Rights Article 14 states that "The enjoyment of the rights and freedoms set forth in [the] Convention shall be secured without discrimination on any ground such as sex, race, colour, language, religion, political or other opinion, national or social origin, association with a national minority, property, birth or other status (10)." In this manner, putting extra prohibitions on lockdowns of +65 population can be debated in terms of discriminatory action. The lockdowns prevent old people living alone from accessing to their basic needs and government is insufficient to provide special service to these group. Besides, the necessity of lockdowns on elder group can also be contested, because a great proportionate of elders living with the other family members of younger age are not protected from the risk of contamination which was the main reason why this lockdown order was on board in the first place. There also should be noted that the lockdown specialized for the +65 population led to the misconception that the only segment of society to be affected by the epidemic is old people. Thus, this perception further contributed to the social discrimination of the elderly (11).
The lockdown consequences can be discussed also as a violation of Article 8, "Everyone has the right to respect for his private and family life, his home and his correspondence. There shall be no interference by a public authority with the exercise of this right except such as is in accordance with the law and is necessary in a democratic society in the interests of national security, public safety or the economic well-being of the country, for the prevention of disorder or crime, for the protection of health or morals, or for the protection of the rights and freedoms of others." Because of the lockdowns and the prohibitions of public transportation, old people have to stay away from their loved ones. Despite the pandemic obliges people staying in their homes, the alternative services that government can provide is insufficient. The usage of internet is very limited in older ages and the alternative platforms to reach out to family support usually needs an online connection.

Therefore, the sufferings of older people as a result of the measurements taken by the government indicates that these implications were already done in a way that disregards the older population. According to the UN (12), by 2050, it is estimated that there will be 1.55 billion people in the world ages 65 and older, which will be 15.8 percent of the population (UN, 2019). This could mean that the older population is the fastest-growing population in the world, so, the economically, politically and culturally effectiveness of this demographic group in society is something that cannot be ignored. Consequently, the measures taken against COVID19 ought to be arranged with the cooperation of the elderly, cover peculiar needs of the elderly, ensure the right to the highest possible physical and mental health criteria, guarantee their access to life-saving treatments and protect their social and financial well-being on equal terms with others.

Correspondence address: Student, Dicle Kaya, Bogazici University, Faculty of Administrative and Economic Sciences, Political Science and International Relations, Istanbul, Turkey kayadicle97@gmail.com 


\section{REFERENCES}

1. Human Rights Watch. Rights Risks to Older People in Covid19 Response. 2020. https://www.hrw.org/news/2020/04/07/rightsrisks-older-people-covid-19-response. Erişim Tarihi: 16 Şubat 2021.

2. ReliefWeb. HelpAge. Neglect and Abuse of Older People Around the World Intensified by Covid-19. 2020. https://reliefweb.int/report/world/neglect-and-abuse-older-people-around-world-intensified-covid-19. Erişim Tarihi: 16 Şubat 2021

3. Akerkar, S. Affirming Radical Equality in the Context of COVID-19: Human Rights of Older People and People with Disabilities. J Hum Rights Pract 2020;12:276-283. doi:10.1093/jhuman/huaa032.

4. Türk, A. Koronavirüs (COVID-19) Pandemisi Sürecinde Yaşlılara Yönelik Uygulamalar ve Yaşlıların Psiko-Sosyal Durumu Üzerine bir Değerlendirme. SHUDER 2020; 35-46.

5. Kaya, M. Koronavirüs Salgınında Yaşlılar Nasıl Hedef Haline Geldi? Seta Perspektif 2020; 271:1-4.

6. Altın, Z. Covid-19 Pandemisinde Yaşlılar. Tepecik Eğit. ve Araşt. Hast. Dergisi 2020; 30 (Suppl 1): 49-57. doi:10.5222/terh.2020.93723.

7. Atila Demir S. Salgın sürecinde yaşlı nüfus, sosyal dışlanma ve yaş ayrımcılığı. Süleyman Demirel Üni. Sosyal Bilimler Enst. Dergisi 2020; 38: 186-201.

8. Yaşlı Hakları Derneği. 65 Yaş Üstü Bireylere Sokağa Çıkma Yasağı Konusunda Basın Açıklaması. 2020. https://yaslihaklarid- ernegi.org/65-yas-ustu-bireylere-sokaga-cikma-yasagi-konusunda-basin-aciklamasi/. Erişim Tarihi: 16 Şubat 2021.

9. Güler, B. İdarenin Covid-19 Pandemisine İlişkin Sokağa Çıkma Yasağı Kararlarının Kanuni İdare İlkesi Kapsamında Değerlendirilmesi. İstanbul Ticaret Üni. Sosyal Bilimler Dergisi Covid-19 Hukuk Özel Sayısı 2020; 38/2 (Suppl 2):180-201.

10. Council of Europe. European Convention for the Protection of Human Rights and Fundamental Freedoms, as amended by Protocols Nos. 11 and 14. ETS 5, 1950. https://www.refworld.org/docid/3ae6b3b04.html. Erişim Tarihi: 16 Şubat 2021.

11. UN. Ageing. 2019. https://www.un.org/en/sections/issuesdepth/ageing/ Erişim Tarihi: 16 Şubat 2021.

12. Türkiye İnsan Hakları Vakfı. Türkiye'de İlk Vakanın Tespit Edildiği 11 Mart ile 10 Mayıs 2020 Tarihleri Arasında Yaşanan Covid-19 Salgını ile İlişkili Hak İhlalleri Raporu (Rep.) Istanbul, Turkey, 2020. 